\title{
Benzothienoquinolines: new one-pot synthesis and fluorescence studies of their interaction with DNA and polynucleotides
}

\author{
A. Rita O. Rodrigues, ${ }^{1}$ M. Solange D. Carvalho, ${ }^{1,2}$ J. André V. Cardoso ${ }^{1}$, Ricardo C. Calhelha, ${ }^{2}$ \\ Maria-João R. P. Queiroz, ${ }^{2}$ Paulo J. G. Coutinho, ${ }^{1}$ Elisabete M.S. Castanheira, ${ }^{1, *}$ \\ ${ }^{1}$ Centro de Física (CFUM), Universidade do Minho, Campus de Gualtar, 4710-057 Braga, Portugal \\ ${ }^{2}$ Centro de Química, Universidade do Minho, Campus de Gualtar, 4710-057 Braga, Portugal
}

\section{REVISED VERSION}

\section{Corresponding Author:}

E. M. S. Castanheira

Centro de Física, Universidade do Minho,

Campus de Gualtar,

4710-057 Braga, Portugal

Phone: +351 253 604321;

Fax: +351253604061

ecoutinho@fisica.uminho.pt

\section{Graphical abstract}
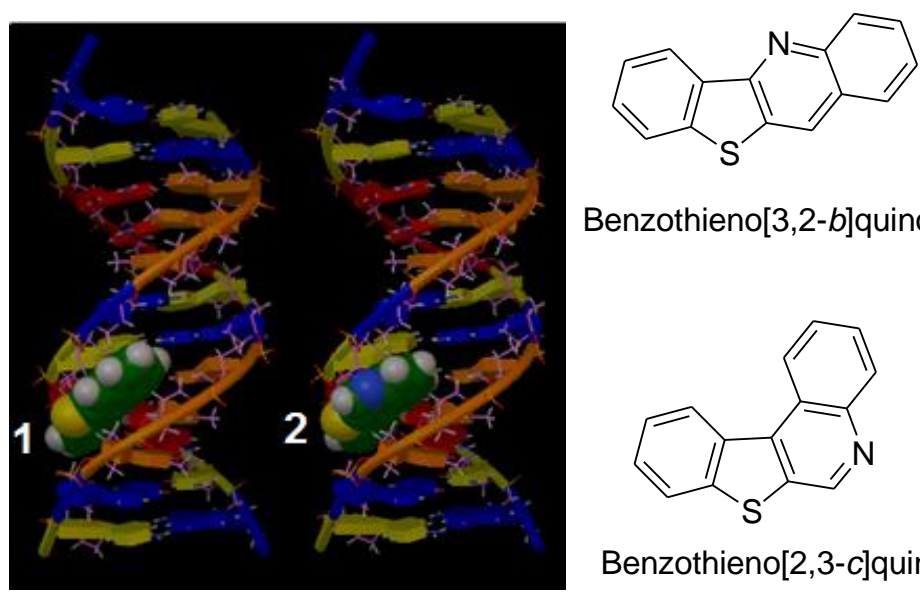

Benzothieno[3,2-b]quinoline 1

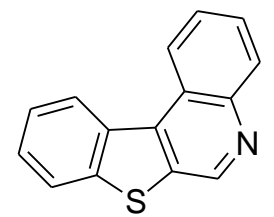

Benzothieno[2,3-c]quinoline 2 


\section{ABSTRACT}

In this work, we were able to obtain the benzothieno[3,2- $b$ ]quinoline 1 and benzothieno[2,3c] quinoline 2 using a new one-pot procedure from the reaction of the commercially available 3bromobenzo $[b]$ thiophene-2-carbaldehyde with 2-aminophenylpinacolborane under Suzuki coupling conditions using a stereochemically hindered ligand, 2(cyclohexylphosphane)biphenyl and $\mathrm{Ba}(\mathrm{OH})_{2} \cdot 8 \mathrm{H}_{2} \mathrm{O}$ as the base.

Fluorescence properties of the benzothieno[3,2-b]quinoline $\mathbf{1}$ and the benzothieno[2,3c] quinoline 2 were studied in solvents of different polarity. Both compounds exhibit a solvent sensitive emission, compound 1 being less fluorescent $\left(\Phi_{\mathrm{F}}<0.05\right)$ than compound $2\left(0.04 \leq \Phi_{\mathrm{F}}\right.$ $\leq 0.10)$.

The interaction of these compounds with salmon sperm DNA and synthetic double-stranded heteropolynucleotides, poly $(\mathrm{dA}-\mathrm{dT}) \cdot(\mathrm{dA}-\mathrm{dT})$ and poly $(\mathrm{dG}-\mathrm{dC}) \cdot(\mathrm{dG}-\mathrm{dC})$, was studied using spectroscopic methods, allowing the determination of the intrinsic binding constants and binding site sizes. The interaction of both compounds is stronger with adenine-thymine (A-T) base pairs. Compound $\mathbf{1}$ is the most intercalative in salmon sperm DNA (47\%) and polynucleotides (46\%-49\% of intercalated molecules), while for compound $2,41 \%$ is intercalated in salmon sperm DNA and only $8 \%$ in poly $(\mathrm{dG}-\mathrm{dC}) \cdot(\mathrm{dG}-\mathrm{dC})$. Docking studies indicate that compound $\mathbf{1}$ interacts more strongly with DNA than compound $\mathbf{2}$, with a significant value of binding free energy in the case of intercalation. Minor groove binding is also very favorable and, probably, both mechanisms occur with a preponderance of intercalation in the case of compound $\mathbf{1}$.

Overall, these results indicate that both benzothienoquinolines interact with nucleic acids by both intercalation and groove binding.

KEYWORDS: Benzothieno[3,2- $b]$ quinoline; Benzothieno[2,3-c]quinoline; DNA interaction; polynucleotides; fluorescence; docking studies.

\section{INTRODUCTION}

The investigation of the nature and dynamics of the binding of small molecules to biomacromolecules is actually an active area of research $[1,2]$. DNA interaction studies are important to understand the mechanism of action of antitumor and antiviral drugs and to design 
new DNA-targeted drugs [3,4]. Three different modes of binding to DNA have been described: intercalation into the base pairs, in the major or minor grooves, and outside the double helix by electrostatic interactions. Small molecules are stabilized in groove binding and intercalation with DNA through a series of associative interactions such as $\pi$-stacking, hydrogen bonding, attractive van der Waals and hydrophobic interactions [4]. DNA intercalation seems to be an essential, but not sufficient, step for antitumoral activity [3].

Benzothieno[3,2-b]quinoline 1 [5] and benzothieno[2,3-c]quinoline 2 [6] are known for their anti-plasmodic and anti-infectious activities, acting mainly through intercalation between DNA base pairs when used in their salt form. Earlier synthesized by separated reactions and in several steps $[5,6]$, in this work we were able to obtain the two compounds in a one pot procedure.

The interactions of the biologically active compounds with nucleic acids have been studied using a variety of techniques [7-11], including absorption and fluorescence spectroscopies. The binding of the fluorescent polycyclic molecules to DNA can be conveniently investigated by these methods, because their absorption and emission properties significantly change on complex formation [7,12,13]. Fluorescence quenching experiments using external quenchers have been used to establish the DNA binding modes, since intercalated fluorophores are less accessible to anionic quenchers, due to electrostatic repulsion by the negatively charged DNA backbone [13-15].

In this work, the interaction of the synthesized benzothienoquinolines $\mathbf{1}$ and $\mathbf{2}$ with natural double-stranded salmon sperm DNA and with synthetic $d s$-polyheteronucleotides was investigated by fluorescence emission measurements. These studies are important due to the biological relevance of both compounds as potential antitumorals.

\section{EXPERIMENTAL}

\subsection{Synthesis}

\section{General remarks}

Melting points $\left({ }^{\circ} \mathrm{C}\right)$ were determined in a SMP3 Stuart apparatus and are uncorrected. ${ }^{1} \mathrm{H}$ and ${ }^{13} \mathrm{C}$ NMR spectra were recorded on a Varian Unity Plus at 300 and $75.4 \mathrm{MHz}$, respectively. Heteronuclear correlations, ${ }^{1} \mathrm{H}_{-}{ }^{13} \mathrm{C}$, HMQC or $\mathrm{HMBC}$ were performed to attribute some signals. HRMS data were recorded using a method of direct injection by EI by the mass 
spectrometry service of the University of Vigo, Spain. The reactions were monitored by thin layer chromatography (TLC) in aluminium plates covered with a layer of silica gel 60 (Macherey-Nagel) of $0.2 \mathrm{~mm}$, with UV254 fluorescence indicator. Column chromatography was performed using silica-gel $230-400$ mesh. Petroleum ether refers to the $40-60{ }^{\circ} \mathrm{C}$ boiling range fraction.

One pot synthesis of benzothieno[3,2-b]quinoline 1 and benzothieno[2,3-c]quinoline 2: To a solution of 3-bromobenzo[b]thiophene-2-carbaldehyde $(150 \mathrm{mg}, 0.600 \mathrm{mmol})$ in dioxane (5 $\mathrm{mL}) \mathrm{Pd}(\mathrm{AcO})_{2}$ (5 mol\%), 2-(cyclohexylphosphane)biphenyl (20 mol\%), $\mathrm{Ba}(\mathrm{OH})_{2} .8 \mathrm{H}_{2} \mathrm{O}$ (3 equiv.) and 2-aniline pinacolborane $(170 \mathrm{mg}, 0.780 \mathrm{mmol})$. The mixture was heated at $100{ }^{\circ} \mathrm{C}$ for 5h. After cooling, $\mathrm{H}_{2} \mathrm{O}$ and AcOEt were added and the phases were separated. The organic phase was dried $\left(\mathrm{MgSO}_{4}\right)$, filtered and the removal of the solvent gave an oil which was dissolved in a small amount of ether and filtered through silica gel column packed and prewashed with petroleum ether. Two bands were eluted; compound 1 with $10 \%$ ether/petroleum ether, and compound 2 using 20\% ether/petroleum ether.

Compound 1 was the major product and was isolated as a colourless solid (45.0 mg, 30\%), m.p. $173-175^{\circ} \mathrm{C}[5] .{ }^{1} \mathrm{H}$ NMR $\left(\mathrm{CDCl}_{3}, 300 \mathrm{MHz}\right): \delta$ 7.55-7.67 $(3 \mathrm{H}, \mathrm{m}, \mathrm{Ar}-\mathrm{H}), 7.74-7.81(1 \mathrm{H}$, m, Ar-H), 7.84-7.94 (2H, m, Ar-H), 8.31 (1H, d, J = 8.4 Hz, Ar-H), 8.59 (1H, s, 11-H), 8.66$8.71(1 \mathrm{H}, \mathrm{m}, \mathrm{Ar}-\mathrm{H}) \mathrm{ppm} .{ }^{13} \mathrm{C} \mathrm{NMR}\left(\mathrm{CDCl}_{3}, 75.4 \mathrm{MHz}\right): \delta 123.04(\mathrm{CH}), 124.01(\mathrm{CH}), 125.08$ $(\mathrm{CH}), 126.19(\mathrm{CH}), 126.60(\mathrm{C}), 127.08(\mathrm{CH}), 128.89(11-\mathrm{CH}), 129.06(\mathrm{CH}), 129.42(\mathrm{CH})$, $129.90(\mathrm{CH}), 130.61$ (C), 134.14 (C), 141.17 (C), 146.44 (C), 153.96 (C). MS (EI): m/z (\%) $235\left(\mathrm{M}^{+}, 100\right)$. HRMS M${ }^{+}$: Calculated for $\mathrm{C}_{15} \mathrm{H}_{9} \mathrm{NS}$ : 235.0456; Found: 235.0449 .

Compound 2 was isolated as a colourless solid (28.0 mg, $20 \%)$, m.p. 123-125 ${ }^{\circ} \mathrm{C}$ [6]. ${ }^{1} \mathrm{H}$ NMR $\left(\mathrm{CDCl}_{3}, 300 \mathrm{MHz}\right): \delta$ 7.61-7.70 (2H, m, Ar-H), 7.74-7.82 (2H, m, Ar-H), 8.05-8.11 (1H, m, Ar-H), 8.30-8.36 (1H, m, Ar-H), 8.84-8.94 (2H, m, Ar-H), 9.37 (1H, s, 6-H) ppm. ${ }^{13} \mathrm{C}$ NMR $\left(\mathrm{CDCl}_{3}, 75.4 \mathrm{MHz}\right): \delta 122.92(\mathrm{CH}), 123.77(\mathrm{CH}), 125.39(\mathrm{CH}+\mathrm{C}), 126.04(\mathrm{CH}), 127.49(\mathrm{CH})$, $127.51(\mathrm{CH}), 127.76(\mathrm{CH}), 130.81(\mathrm{CH}), 133.37(\mathrm{C}), 135.15(\mathrm{C}), 135.37(\mathrm{C}), 141.35(\mathrm{C})$, 145.56 (C), 145.65 (6-CH) [6b]. MS (EI): m/z (\%) $235\left(\mathrm{M}^{+}, 100\right)$. HRMS M+: Calculated for $\mathrm{C}_{15} \mathrm{H}_{9} \mathrm{NS}: 235.0456$; Found: 235.0457.

The data for both compounds are identical to the ones published elsewhere [5,6], but those are not so complete as in this work. 


\subsection{Spectroscopic measurements}

Absorption spectra were recorded in a Shimadzu UV-3101PC UV-Vis-NIR spectrophotometer. Fluorescence measurements were performed using a Fluorolog 3 spectrofluorimeter, equipped with double monochromators in both excitation and emission and a temperature-controlled cuvette holder. For fluorescence quantum yield determination, the solutions were previously bubbled for 30 minutes with ultrapure nitrogen. Fluorescence spectra were corrected for the instrumental response of the system.

The fluorescence quantum yields $\left(\Phi_{\mathrm{s}}\right)$ were determined using the standard method (equation 1) $[16,17]$ and 9,10-diphenylanthracene in ethanol as reference, $\Phi_{\mathrm{r}}=0.95$ at $25{ }^{\circ} \mathrm{C}$ [18].

$$
\Phi_{\mathrm{s}}=\left\lfloor\left(A_{\mathrm{r}} F_{\mathrm{S}} n_{\mathrm{S}}^{2}\right) /\left(A_{\mathrm{s}} F_{\mathrm{r}} n_{\mathrm{r}}^{2}\right)\right\rfloor \Phi_{\mathrm{r}}
$$

where $A$ is the absorbance at the excitation wavelength, $F$ the integrated emission area and $n$ the index of refraction of the solvents used. Subscripts refer to the reference (r) or sample (s) compound.

All solutions were prepared using spectroscopic grade solvents and Milli-Q grade water. Natural double-stranded salmon sperm DNA was obtained from Invitrogen, while synthetic double-stranded heteropolynucleotides, poly $(\mathrm{dA}-\mathrm{dT}) \cdot(\mathrm{dA}-\mathrm{dT})$ and poly $(\mathrm{dG}-\mathrm{dC}) \cdot(\mathrm{dG}-\mathrm{dC})$, were obtained from Sigma-Aldrich. Salmon sperm DNA, polynucleotides and compounds stock solutions were prepared in $10^{-2} \mathrm{M}$ Tris- $\mathrm{HCl}$ buffer $(\mathrm{pH}=7.2)$, with $10^{-3} \mathrm{M}$ EDTA. The purity of DNA was checked by monitoring the absorption spectrum and the ratio of the absorbance at 260 and $280 \mathrm{~nm}, \mathrm{~A}_{260} / \mathrm{A}_{280}=1.95$ (good-quality DNA exhibits an $\mathrm{A}_{260} / \mathrm{A}_{280}$ ratio higher than 1.8 [19]). The DNA and polynucleotide concentrations in number of bases (or phosphate groups) were determined from the molar absorption coefficients [12], $\varepsilon=6600$ $\mathrm{M}^{-1} \mathrm{~cm}^{-1}$ at $260 \mathrm{~nm}$ for DNA, $\varepsilon=8400 \mathrm{M}^{-1} \mathrm{~cm}^{-1}$ at $254 \mathrm{~nm}$ for poly $(\mathrm{dG}-\mathrm{dC}) \cdot(\mathrm{dG}-\mathrm{dC})$ and $\varepsilon=$ $6600 \mathrm{M}^{-1} \mathrm{~cm}^{-1}$ at $260 \mathrm{~nm}$ for poly $(\mathrm{dA}-\mathrm{dT}) \cdot(\mathrm{dA}-\mathrm{dT})$.

The absorption and emission spectra of several solutions with different [nucleic acid]/[compound] ratios using the same compound concentration $\left(2 \times 10^{-6} \mathrm{M}\right)$ were recorded. The solutions were left $24 \mathrm{~h}$ to stabilize. The absorbance at excitation wavelengths was always less than 0.1 , in order to avoid inner filter effects. All measurements were performed at room temperature $\left(25.0 \pm 0.5^{\circ} \mathrm{C}\right)$. Binding analysis of the experimental data was performed according to McGhee and von Hippel model [20] to determine the intrinsic binding constants 
and the binding site sizes (the number of base pairs between consecutive bound ligand molecules).

\section{RESULTS AND DISCUSSION}

\subsection{Synthesis}

The reaction of the commercially available 3-bromobenzo[b]thiophene-2-carbaldehyde with 2-aminophenylpinacolborane under Suzuki coupling conditions using a stereochemically hindered ligand as 2-(cyclohexylphosphane)biphenyl [21] and $\mathrm{Ba}(\mathrm{OH})_{2} .8 \mathrm{H}_{2} \mathrm{O}$ as the base, gave in a one-pot procedure compounds $\mathbf{1}$ and $\mathbf{2}$, which were separated by column chromatography (Scheme 1).

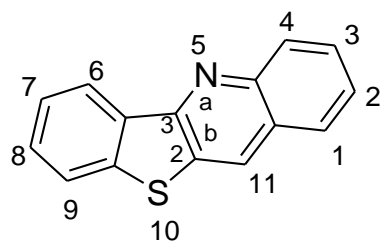

Benzothieno[3,2-b]quinoline<smiles>CC1(C)OB(c2ccccc2N)OC1(C)C</smiles>

$1,30 \%$

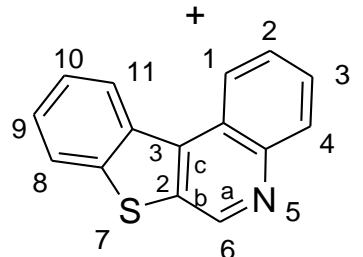

Benzothieno[2,3-c]quinoline

$2,20 \%$

i) $\mathrm{Pd}(\mathrm{OAc})_{2}$ (5 mol\%), 2-(cyclohexylphosphane)biphenyl (20 mol\%), Ba(OH) $)_{2} \cdot 8 \mathrm{H}_{2} \mathrm{O}$ (3 equiv.), dioxane, $100{ }^{\circ} \mathrm{C}$, $5 \mathrm{~h}$.

Scheme 1. One pot synthesis of benzothieno[3,2-b]quinoline 1 and benzothieno[2,3-c]quinoline 2.

Although these compounds have already been synthesized by other authors in several steps, we were able to prepare them in a one-pot procedure, which is very advantageous to save reagents and time.

Using these reaction conditions, the formation of compound 1 was unexpected. It seems that it is the result of a Pd-catalyzed $\mathrm{C}-\mathrm{N}$ coupling followed by an intramolecular cyclization that may occur by nucleophilic attack of the activated ortho position of the diarylamine intermediate on the carbonyl of the aldehyde, after deboronation (Scheme 2). 


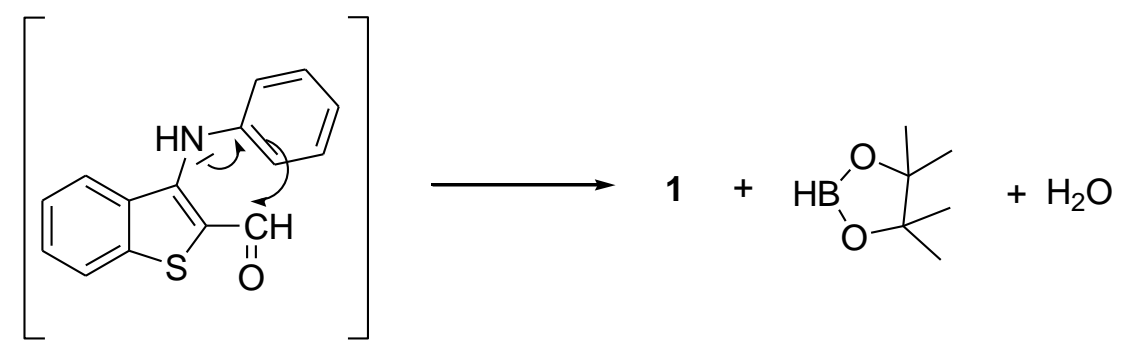

Scheme 2. Proposed intermediate and products for the reaction of synthesis of compound $\mathbf{1}$.

In the synthesis of the expected compound 2, a Suzuki cross-coupling and a nucleophilic attack of the amino group on the aldehyde occurred.

\subsection{Fluorescence studies in several solvents}

The absorption and fluorescence properties of compounds $\mathbf{1}$ and $\mathbf{2}$ were studied in several solvents of different polarity. The maximum absorption $\left(\lambda_{\text {abs }}\right)$ and emission wavelengths $\left(\lambda_{\text {em }}\right)$ and fluorescence quantum yields $\left(\Phi_{\mathrm{F}}\right)$ of both compounds in several solvents are presented in Table 1. The normalized fluorescence spectra are shown in Figures 1 and 2 (examples of absorption spectra are also shown as insets).

Fluorescence emission was exhibited by compounds $\mathbf{1}$ and $\mathbf{2}$ in several non-polar and polar solvents, including water. Fluorescence quantum yield values are generally low, varying from $2 \%$ to $10 \%$ (Table 1), the benzothieno[2,3-c] quinoline 2 being the most fluorescent compound. A red-shift and loss of vibrational structure is observed for the emission in polar solvents, this effect being more pronounced for compound 1 (red shifts between cyclohexane and water are $48 \mathrm{~nm}$ for compound 1 and $28 \mathrm{~nm}$ for compound 2). In the absorption spectra the red shifts are negligible (Table 1), this behavior indicating that solvent relaxation after photoexcitation plays an important role, especially for the benzothieno[3,2-b]quinoline 1. This predicts a higher ICT character of the excited state for the latter compound. 


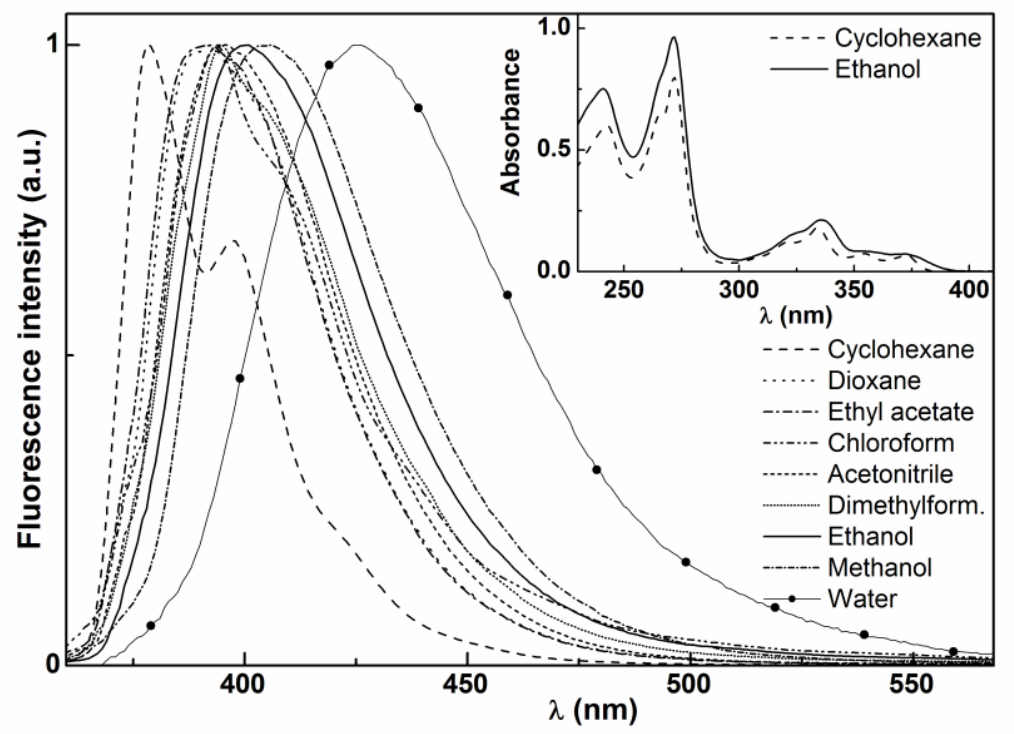

Figure 1. Normalized fluorescence spectra of solutions $\left(3 \times 10^{-6} \mathrm{M}\right)$ of compound $\mathbf{1}\left(\lambda_{\mathrm{exc}}=335 \mathrm{~nm}\right)$ in several solvents. Inset: absorption spectra of $2 \times 10^{-5} \mathrm{M}$ solutions of compound $\mathbf{1}$ in cyclohexane and ethanol, as examples.

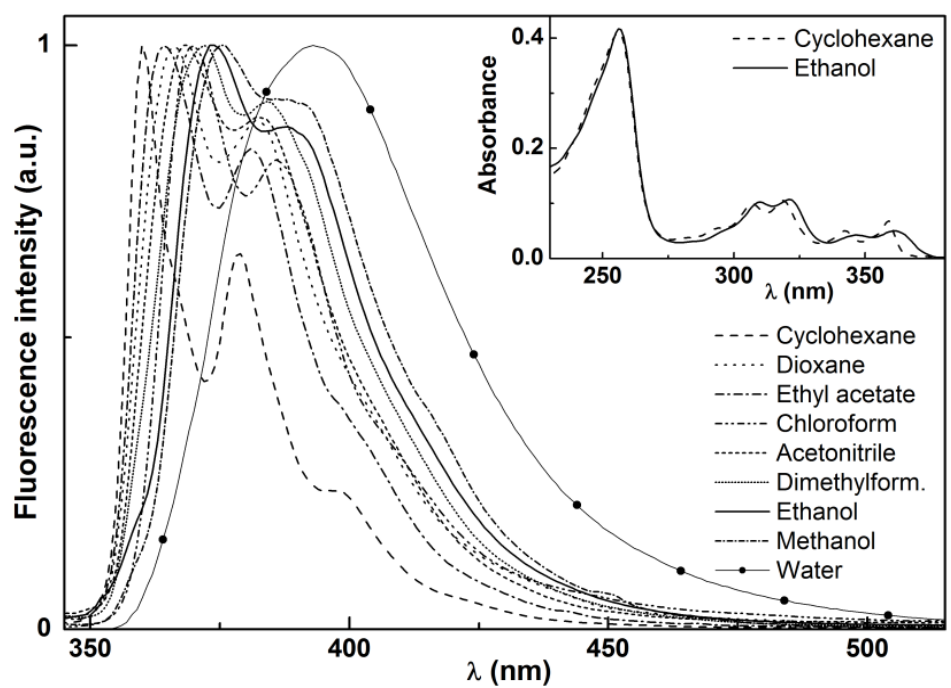

Figure 2. Normalized fluorescence spectra of solutions $\left(3 \times 10^{-6} \mathrm{M}\right)$ of compound $2\left(\lambda_{\text {exc }}=325 \mathrm{~nm}\right)$ in several solvents. Inset: Absorption spectra of $10^{-5} \mathrm{M}$ solutions of compound 2 in cyclohexane and ethanol, as examples. 
Table 1. Maximum absorption $\left(\lambda_{\mathrm{abs}}\right)$ and emission wavelengths $\left(\lambda_{\mathrm{em}}\right)$ and fluorescence quantum yields $\left(\Phi_{\mathrm{F}}\right)$ of compounds $\mathbf{1}$ and $\mathbf{2}$ in several solvents.

\begin{tabular}{|c|c|c|c|c|c|c|}
\hline \multirow[t]{2}{*}{ Solvent } & \multicolumn{2}{|c|}{$\lambda_{\text {abs }}(\mathbf{n m})$} & \multicolumn{2}{|c|}{$\lambda_{\mathrm{em}}(\mathbf{n m})$} & \multicolumn{2}{|c|}{$\Phi_{\mathrm{F}}^{\mathrm{a}}$} \\
\hline & 1 & 2 & 1 & 2 & 1 & 2 \\
\hline Cyclohexane & $372,354,334,272,243$ & $359,342,319,307,256$ & 378 & 364 & 0.02 & 0.07 \\
\hline Dioxane & $372,354,335,272,242$ & $359,343,320,308,257$ & 392 & 367 & 0.03 & 0.10 \\
\hline Ethylacetate $^{\mathrm{b}}$ & $371,353,334,271$ & $358,342,318,307$ & 393 & 365 & 0.02 & 0.08 \\
\hline Dichloromethane & $372,354,336,273,243$ & $360,344,321,309,257$ & 392 & 370 & 0.02 & 0.06 \\
\hline Chloroform $^{\mathrm{b}}$ & $374,356,337,274$ & $361,345,322,310,258$ & 394 & 372 & 0.02 & 0.04 \\
\hline Acetonitrile & $371,353,334,270,241$ & $358,342,319,307,255$ & 394 & 369 & 0.02 & 0.05 \\
\hline$N, N$-Dimethylformamide ${ }^{\mathrm{b}}$ & $372,355,335$ & $360,344,320,309$ & 395 & 384 & 0.04 & 0.08 \\
\hline Dimethylsulfoxide $^{\mathrm{b}}$ & $373,356,337$ & $360,344,322,310$ & 403 & 374 & 0.03 & 0.08 \\
\hline Ethanol & $372,336,272,241$ & $361,347,321,310,256$ & 401 & 374 & 0.03 & 0.09 \\
\hline Methanol & $371,336,271,240$ & $361,346,321,310,256$ & 406 & 375 & 0.02 & 0.07 \\
\hline Water & $372,336,271,240$ & $362,349,321,311,255$ & 426 & 392 & 0.01 & 0.06 \\
\hline
\end{tabular}

${ }^{a}$ Relative to 9,10-diphenylanthracene in ethanol $\left(\Phi_{\mathrm{R}}=0.95\right)$ [18]. Error about $10 \%$.

${ }^{\text {b}}$ Solvents cut-off: Chloroform: $250 \mathrm{~nm}$; Ethyl acetate: $265 \mathrm{~nm} ; \quad N, N$-dimethylformamide: $280 \mathrm{~nm}$. Dimethylsulfoxide: $275 \mathrm{~nm}$.

The fluorescence quantum yields in protic solvents tend to decrease with increasing solvent hydrogen bonding capability $\left(\Phi_{\mathrm{F}}\right.$ in ethanol $>\Phi_{\mathrm{F}}$ in methanol $>\Phi_{\mathrm{F}}$ in water $)$. This may be due to an increase of $\mathrm{S} \rightarrow \mathrm{T}$ intersystem crossing efficiency through $\mathrm{H}$-bond formation between these quinoline derivatives and protic solvents, probably by protonation of the $\mathrm{N}$ atom of the pyridine moiety. A similar behaviour was observed for several thieno[3,2-b]pyridine derivatives synthesized in our lab [22-24]. The formation of hydrogen bonds between chloroform and these proton acceptor quinoline derivatives can also explain the lower fluorescence quantum yield values in this solvent [25,26].

The ground state dipole moment $\left(\mu_{\mathrm{g}}\right)$ and the excited state dipole moment $\left(\mu_{\mathrm{e}}\right)$ for benzothienoquinolines 1 and $\mathbf{2}$ (Table 2) were determined performing ab initio molecular quantum chemistry calculations with Gaussian 09 software [27], using a 6-311++G(d,p) basis set at the TD-SCF DFT (MPW1PW91) level of theory [28] in gas phase. The optimized geometries of the ground and excited states show that both molecules have a planar geometry (Figure 3). The dipole moment vector changes upon excitation, increasing in magnitude for both compounds, with a significant change in direction in the case of compound $\mathbf{1}$. 


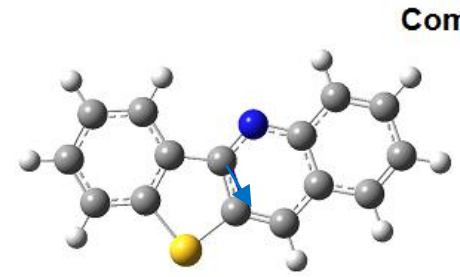

Ground state

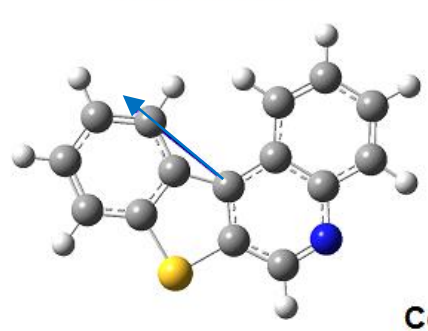

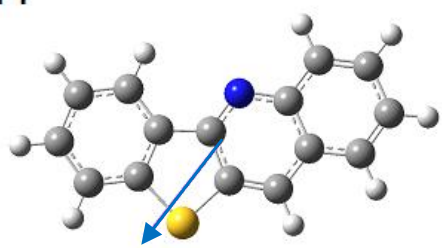

Excited state

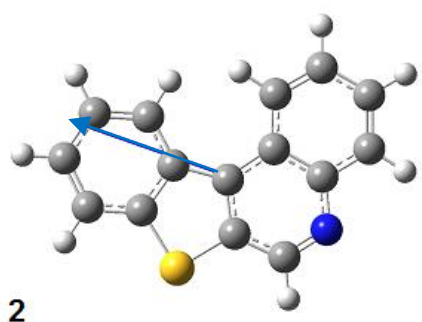

Compound 2

Figure 3. Optimized geometries of compounds 1 and $\mathbf{2}$ obtained by Gaussian 09 software (grey: C atoms; white: $\mathrm{H}$ atoms; blue: $\mathrm{N}$ atoms; yellow: $\mathrm{S}$ atoms). Left: ground state; Right: lowest excited singlet state. The arrows indicate the direction of the dipole moment.

Table 2. Ground $\left(\mu_{\mathrm{g}}\right)$ and excited state $\left(\mu_{\mathrm{e}}\right)$ dipole moments obtained from theoretical calculations.

\begin{tabular}{cccc}
\hline Compound & $\begin{array}{c}\text { Molecular } \\
\text { radius }(\AA)\end{array}$ & $\begin{array}{c}\text { Ground state dipole } \\
\text { moment, } \mu_{\mathrm{g}}(\mathrm{D})\end{array}$ & $\begin{array}{c}\text { Excited state dipole } \\
\text { moment, } \mu_{\mathrm{e}}(\mathrm{D})\end{array}$ \\
\hline $\mathbf{1}$ & 4.8 & 0.84 & 3.16 \\
$\mathbf{2}$ & 4.7 & 2.75 & 3.68 \\
\hline
\end{tabular}

Figure 4 shows the representation of HOMO and LUMO orbitals, as well as the corresponding centroids of either the electronic depletion $\left(\mathrm{C}_{+}\right)$or increment $\left(\mathrm{C}_{-}\right)$[29] that occurs upon electronic excitation, using the lowest excited state optimized geometry (relaxed $\mathrm{S}_{1}$ state). Alternating increases and decreases of electronic density are observed in the $\pi$ electron system (Figure 4). The main difference between the two compounds is that for compound 1 there is no electronic density at the $\mathrm{S}$ atom in the LUMO orbital, whereas for compound 2 the electronic density decreases, but does not vanish. Also, a higher degree of charge transfer is observed for compound $\mathbf{1}$ than for compound $\mathbf{2}$, the distance between the barycenters of charge density increase and decrease being $1.24 \AA$ and $0.38 \AA$, respectively. The calculations of densities of charge increase and depletion were performed with the help of the Multiwfn software package [30]. These results are in accordance with the higher solvatochromism experimentally observed for compound $\mathbf{1}$. 


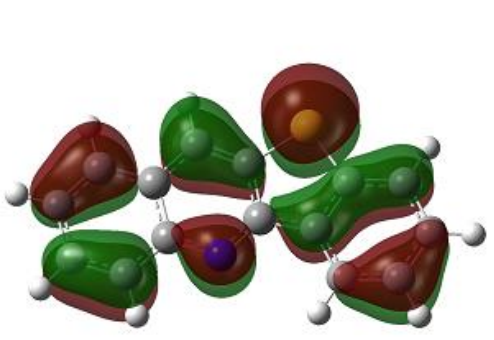

A

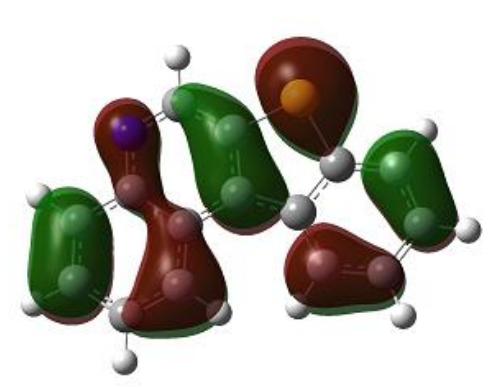

Quinoline 1

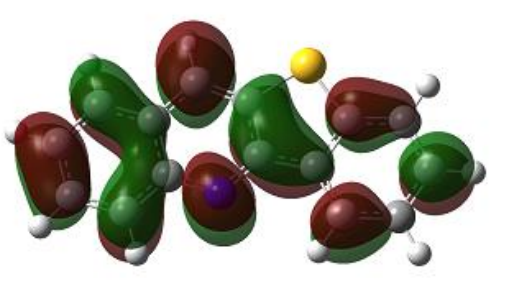

B

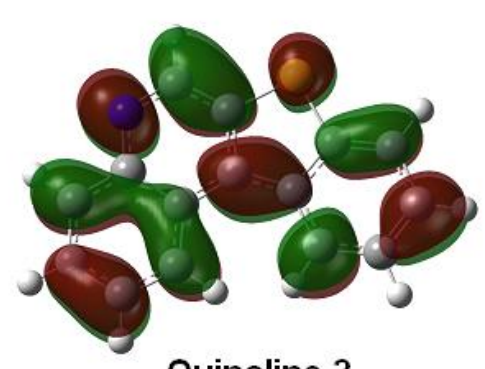

Quinoline 2

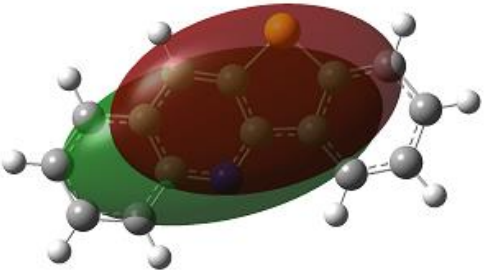

C

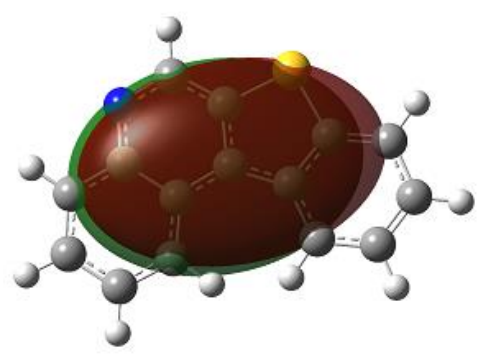

Figure 4. Representation of HOMO orbital (A), LUMO orbital (B) and centroids of charge density

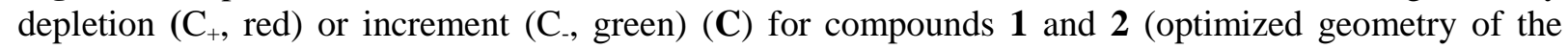
lowest excited singlet state) at an iso level of 0.02 for orbitals and 0.002 for electronic density.

The representation of the energy level diagram with the transition energies for the two quinolines is displayed in Figure 5, in vacuum, cyclohexane and acetonitrile, using optimized geometries for each medium. The solvent was considered as a polarizable continuum model (PCM) using, for the definition of the molecular shape, an united atom topological model with radii optimized for DFT PBE1PBE/6-31G(d) level of theory, and a van der Waals surface (g09 keywords: SCRF=PCM, Radii=UAKSm, Surface=VDW). Comparing with the experimentally observed maxima, the calculated absorption transition energies are slightly shifted to lower wavelengths, although there is a good agreement in the case of acetonitrile for compound $\mathbf{1}$ (Table 1). For emission, the experimental maximum wavelengths are in better accordance with the calculated ones, these being slightly higher. Also, the higher oscillator strengths ( $f$ ) calculated for compound $\mathbf{2}$ are in accordance with its higher fluorescence quantum yields experimentally observed. The calculated oscillator strengths show an increase with solvent polarity. This is compatible with the observed quantum yield values, if solvents for which hydrogen bonding might occur are excluded.

The significant sensitivity of the fluorescence emission of these two benzothienoquinolines to the fluorophore environment can be useful when probing their interactions with DNA and polynucleotides. 

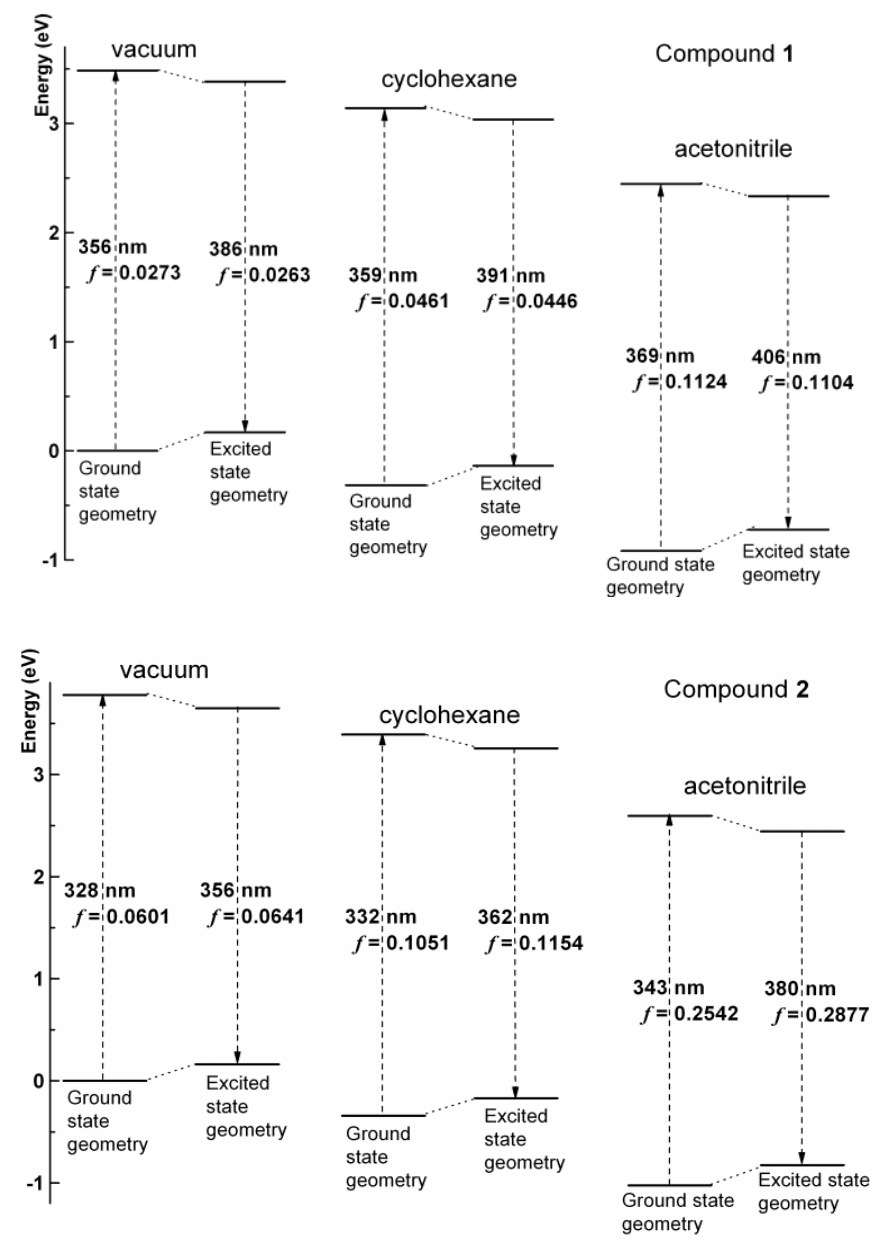

Figure 5. Representation of the energy level diagram, with the transition energies for the benzothienoquinolines $\mathbf{1}$ (above) and $\mathbf{2}$ (below), obtained by molecular quantum chemistry calculations, in vacuum, cyclohexane and acetonitrile.

\subsection{Interaction with salmon sperm DNA and with synthetic double-stranded polynucleotides}

The interaction of compounds $\mathbf{1}$ and $\mathbf{2}$ with natural double-stranded salmon sperm DNA was studied by fluorescence. Changes in absorption spectra upon DNA interaction are negligible, as previously observed for other neutral aromatic compounds studied by some of us, namely tetracyclic lactams [31] and thieno[3,2-b]pyridine derivatives [24]. Figures 6 and 7 show the emission spectra of the benzothienoquinolines $\mathbf{1}$ and $\mathbf{2}$ with increasing [DNA]/[compound] ratio, where [DNA] is expressed in number of bases or phosphate groups. For both quinoline derivatives the emission intensity reaches a limit value for [DNA]/[compound] ratios $\geq 100$, indicating that total compound binding is achieved at this [DNA]/[compound] ratio (spectra corresponding to ratio 100 and 120 are overlapped). 


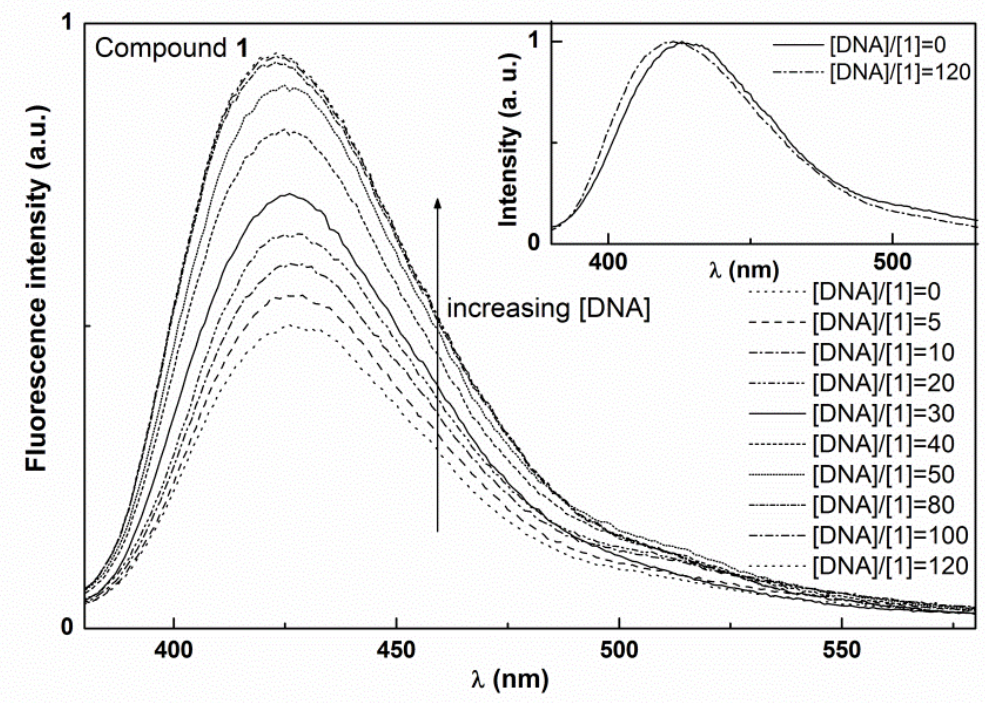

Figure 6. Fluorescence spectra of the benzothienoquinoline $1\left(2 \times 10^{-6} \mathrm{M}\right)$ in $10 \mathrm{mM}$ Tris-HCl buffer $(\mathrm{pH}=7.2)$, with increasing DNA content. Inset: Normalized spectra at [DNA]/[1] $=0$ and 120 .

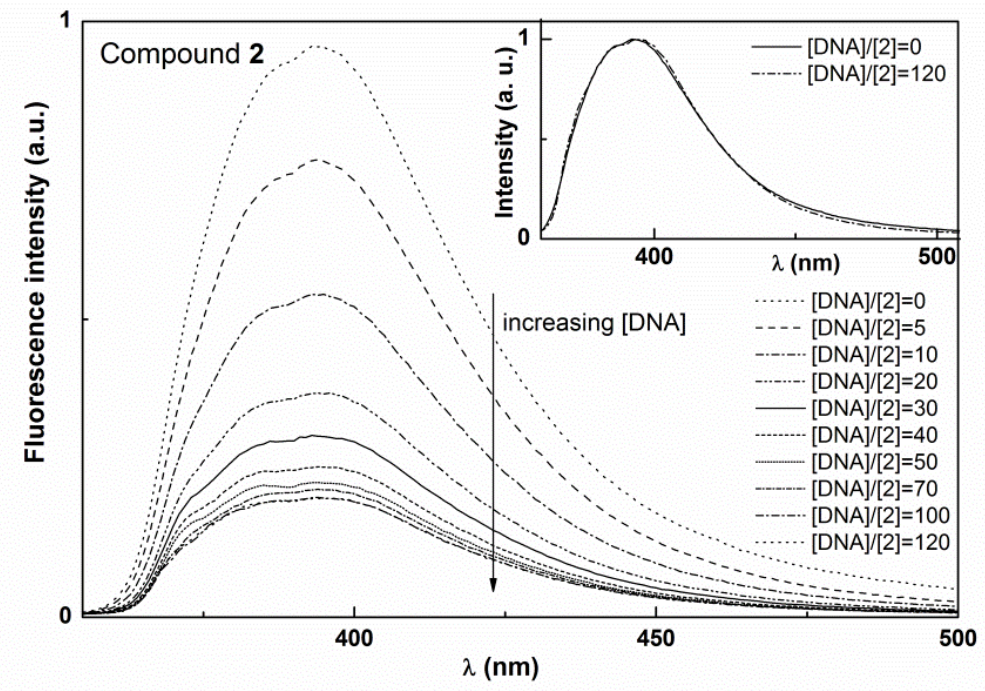

Figure 7. Fluorescence spectra of the benzothienoquinoline $2\left(2 \times 10^{-6} \mathrm{M}\right)$ in $10 \mathrm{mM}$ Tris-HCl buffer $(\mathrm{pH}=7.2)$, with increasing DNA content. Inset: Normalized spectra at [DNA]/[2] $]=0$ and 120.

An enhancement in emission intensity with increasing DNA concentration is observed for compound 1, while the opposite occurs for compound 2 (Figure 8). This may indicate a different type of dominating interaction of the two benzothienoquinolines with DNA bases, as already observed for other tetracyclic compounds [24,31]. Further evidence is given by the occurrence of a slight blue shift upon DNA binding only in the case of compound 1 (inset of figures 6 and 7). The high [DNA]/[compound] ratio needed for total binding, together with the negligible changes observed in absorption spectra (not shown), point to a weak interaction of 
these molecules with the nucleic acid, which is also a common behavior with tetracyclic thienopyridine derivatives [24].

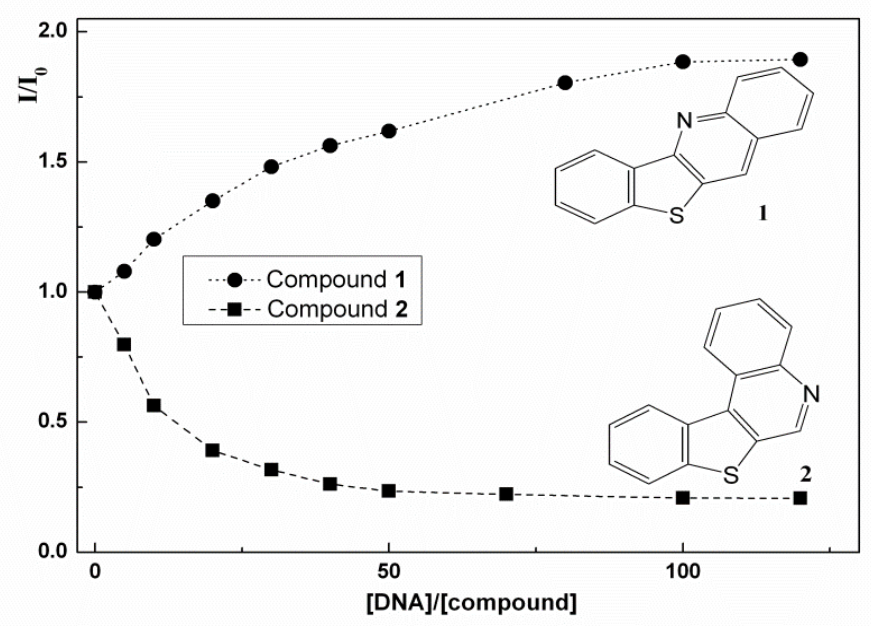

Figure 8. Fluorescence intensities ratio in the presence (I) and absence $\left(\mathrm{I}_{0}\right)$ of DNA for compounds 1 and $\mathbf{2}$ at several [DNA]/[compound] molar ratios.

To clarify the different behavior of the two quinolines, the base sequence binding preference was also investigated, using synthetic $d s$-heteropolynucleotides, poly $(\mathrm{dA}-\mathrm{dT}) \cdot(\mathrm{dA}-$ $\mathrm{dT})$ and poly $(\mathrm{dG}-\mathrm{dC}) \cdot(\mathrm{dG}-\mathrm{dC})$. Figure 9 displays the ratio of maximum emission intensities in the presence (I) and absence $\left(\mathrm{I}_{0}\right)$ of $d s$-heteropolynucleotides for several [nucleic acid]/[compound] ratios, for compounds $\mathbf{1}$ and $\mathbf{2}$, respectively. The behaviour in heteropolynucleotides is similar to that obseved in salmon sperm DNA, with a rise in fluorescence intensity with increasing polynucleotide concentration for compound $\mathbf{1}$ and a decrease for compound 2. However, the stabilization in emission intensity, indicative of full binding, is attained at a significantly lower molar ratio for poly $(\mathrm{dA}-\mathrm{dT}) \cdot(\mathrm{dA}-\mathrm{dT})$ ([nucleotide]/[compound] $=60$ and 80 , respectively for compound $\mathbf{1}$ and $\mathbf{2}$ ). For poly(dG$\mathrm{dC}) \cdot(\mathrm{dG}-\mathrm{dC})$, the stabilization is attained at a molar ratio of 100 for both quinolines, similarly to the behavior observed with salmon sperm DNA. 


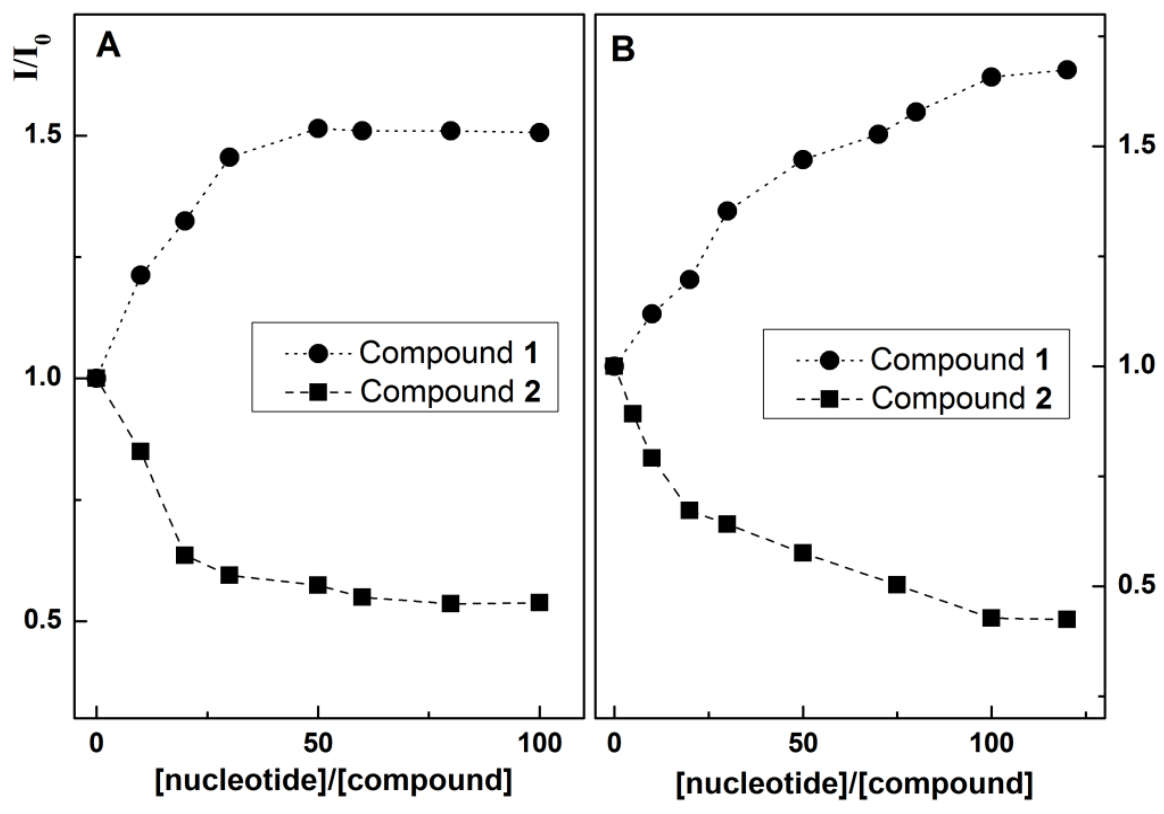

Figure 9. Fluorescence intensities ratio in the presence (I) and absence $\left(\mathrm{I}_{0}\right)$ of heteropolynucleotides for the benzothienoquinolines $\mathbf{1}$ and $\mathbf{2}$ at several [nucleotide]/[compound] molar ratios.

A: poly $(\mathrm{dA}-\mathrm{dT}) \cdot(\mathrm{dA}-\mathrm{dT}) ; \mathbf{B}: \operatorname{poly}(\mathrm{dG}-\mathrm{dC}) \cdot(\mathrm{dG}-\mathrm{dC})$.

The binding constants and binding site sizes were determined by the modified Scatchard equation, given by McGhee and von Hippel [20]

$$
\frac{r}{c_{\mathrm{f}}}=K_{\mathrm{i}}(1-n r)[(1-n r) /[1-(n-1) r]]^{n-1}
$$

where $K_{\mathrm{i}}$ is the intrinsic binding constant, $n$ is the binding site size, $r$ is the ratio $c_{\mathrm{b}} /[$ nucleic acid], $c_{\mathrm{b}}$ and $c_{\mathrm{f}}$ are the concentrations of bound and free compound, respectively, calculated by

$$
\mathrm{c}_{\mathrm{b}}=\frac{\mathrm{I}_{\mathrm{F}, 0}-\mathrm{I}_{\mathrm{F}}}{\mathrm{I}_{\mathrm{F}, 0}-\mathrm{I}_{\mathrm{F}, \mathrm{b}}} \times \mathrm{c}_{\text {total }} \quad ; \quad \mathrm{c}_{\text {total }}=\mathrm{c}_{\mathrm{f}}+\mathrm{c}_{\mathrm{b}}
$$

being $I_{F, 0}$ the fluorescence intensity of the free compound and $I_{F, b}$ the fluorescence intensity of the bound compound at total binding.

The fluorescence measurements results were fitted by least squares methods to obtain the values of the binding constants $\left(K_{\mathrm{i}}\right)$ and the number of base pairs between consecutive intercalated compound molecules $(n)$. The results are presented in Table 3. 
Table 3. Values of binding constants $\left(K_{\mathrm{i}}\right)$ and binding site sizes $(n)$ for benzothienoquinolines interaction with DNA and synthetic heteropolynucleotides.

\begin{tabular}{lccc}
\hline & Nucleic acid & $K_{\mathrm{i}}\left(\mathrm{M}^{-1}\right)$ & $n$ \\
\hline \multirow{3}{*}{ Compound 1 } & salmon sperm DNA & $(2.6 \pm 0.3) \times 10^{5}$ & $14 \pm 5$ \\
& poly $(\mathrm{dA}-\mathrm{dT}) \cdot(\mathrm{dA}-\mathrm{dT})$ & $(3.0 \pm 0.4) \times 10^{5}$ & $13 \pm 5$ \\
& poly $(\mathrm{dG}-\mathrm{dC}) \cdot(\mathrm{dG}-\mathrm{dC})$ & $(5.9 \pm 0.6) \times 10^{4}$ & $35 \pm 9$ \\
\hline \multirow{3}{*}{ Compound 2 } & salmon sperm DNA & $(2.9 \pm 0.3) \times 10^{5}$ & $16 \pm 6$ \\
& poly $(\mathrm{dA}-\mathrm{dT}) \cdot(\mathrm{dA}-\mathrm{dT})$ & $(3.1 \pm 0.4) \times 10^{5}$ & $14 \pm 5$ \\
& poly $(\mathrm{dG}-\mathrm{dC}) \cdot(\mathrm{dG}-\mathrm{dC})$ & $(4.5 \pm 0.5) \times 10^{4}$ & $25 \pm 9$ \\
\hline
\end{tabular}

It has already been reported that small variations in the structure of tetracyclic compounds, as differences only in the substituent groups, influence strongly the interaction with nucleic acids $[13,24,31]$, either by changing the main mechanism or by affecting the magnitude of interaction (binding constant and binding site size). As both compounds exhibit a stronger interaction with poly $(\mathrm{dA}-\mathrm{dT}) \cdot$ poly $(\mathrm{dA}-\mathrm{dT})$ than with poly $(\mathrm{dG}-\mathrm{dC}) \cdot(\mathrm{dG}-\mathrm{dC})$ (higher binding constants and lower binding site sizes in the former), it can be concluded that the main interaction in DNA is established with A-T base pairs. A likely mechanism is intercalation by $\pi-\pi$ stacking. In the present case, differently from the case of other planar aromatics interacting within nucleic acids [32,33], photoinduced electron transfer involving DNA bases is not expected to occur because the process is thermodynamically unfavourable.

Fluorescence quenching experiments with iodide ion were also performed for compounds $\mathbf{1}$ and $\mathbf{2}$ in the presence of DNA and heteropolynucleotides, in the situation of total binding $([\mathrm{DNA}] /[$ compound $]=100, \quad[\operatorname{poly}(\mathrm{dA}-\mathrm{dT}) \cdot(\mathrm{dA}-\mathrm{dT})] /[$ compound $]=80$ and $[$ poly $(\mathrm{dG}-\mathrm{dC}) \cdot(\mathrm{dG}-$ $\mathrm{dC})] /\left[\right.$ compound]=100 for both quinolines $\mathbf{1}$ and $\mathbf{2}$, with $\left[\right.$ compound] $\left.=2 \times 10^{-6} \mathrm{M}\right)$. The quenching data were first plotted according to the Stern-Volmer relation (equation 4) [34],

$$
\frac{I_{0}}{I}=1+K_{\mathrm{SV}}[\mathrm{Q}]
$$

where $I_{0}$ and $I$ are, respectively, the fluorescence intensities in the absence and in the presence of quencher $\left(\mathrm{I}^{-}\right), K_{\mathrm{SV}}$ is the Stern-Volmer constant and [Q] is the quencher concentration.

In all cases, Stern-Volmer plots are non-linear (figure 10, as an example), with a downward curvature. This means that not all the fluorescent molecules are accessible to the quencher. In this case, the system contains heterogeneously emitting sites, in which some compound molecules are accessible to the quencher and other molecules are not accessible. Thus, the Stern-Volmer equation must be modified [35] as (5): 


$$
\frac{I_{0}}{\Delta I}=\frac{1}{f_{\mathrm{a}}}+\frac{1}{f_{\mathrm{a}} K_{\mathrm{SV}}[\mathrm{Q}]}
$$

where $\Delta I=I_{0}-I, f_{\mathrm{a}}$ is the accessibility to quencher. From the plots of $I_{0} / \Delta I v s .1 /[\mathrm{Q}]$, it is possible to obtain the accessibilities to the anionic quencher. The results are summarized on Table 4.

Table 4. Values of the accessibilities $\left(f_{\mathrm{a}}\right)$ to the quencher $\left(\mathrm{I}^{-}\right)$and Stern-Volmer constants for compounds 1 and $\mathbf{2}$ bound to DNA and heteropolynucleotides.

\begin{tabular}{cccc}
\hline & Nucleic acid & $\mathrm{K}_{\mathrm{SV}}\left(\mathrm{M}^{-1}\right)$ & $f_{\mathrm{a}}$ \\
\hline \multirow{3}{*}{ Compound 1 } & Salmon sperm DNA & 4.65 & 0.53 \\
& poly $(\mathrm{dA}-\mathrm{dT}) \cdot(\mathrm{dA}-\mathrm{dT})$ & 9.33 & 0.54 \\
& poly $(\mathrm{dG}-\mathrm{dC}) \cdot(\mathrm{dG}-\mathrm{dC})$ & 11.1 & 0.51 \\
\hline \multirow{2}{*}{ Compound 2 } & Salmon sperm DNA & 8.61 & 0.59 \\
& poly $(\mathrm{dA}-\mathrm{dT}) \cdot(\mathrm{dA}-\mathrm{dT})$ & 9.54 & 0.63 \\
& poly $(\mathrm{dG}-\mathrm{dC}) \cdot(\mathrm{dG}-\mathrm{dC})$ & 6.1 & 0.92 \\
\hline
\end{tabular}

Anionic quenchers can be used to distinguish between DNA binding modes [14,15,35]. Intercalated chromophores are less accessible to quenching by iodide ion due to electrostatic repulsion between the negatively charged DNA and iodide anion [15]. Compounds which are bound at the DNA surface (groove binding or electrostatic binding) are more accessible and, therefore, emission from these molecules can be quenched more efficiently. As these benzothienoquinolines are neutral molecules, electrostatic binding to nucleic acids is not involved. Therefore, the fraction of compound molecules accessible to the external quencher $\left(f_{\mathrm{a}}\right)$ should correspond to bound molecules at the grooves. 


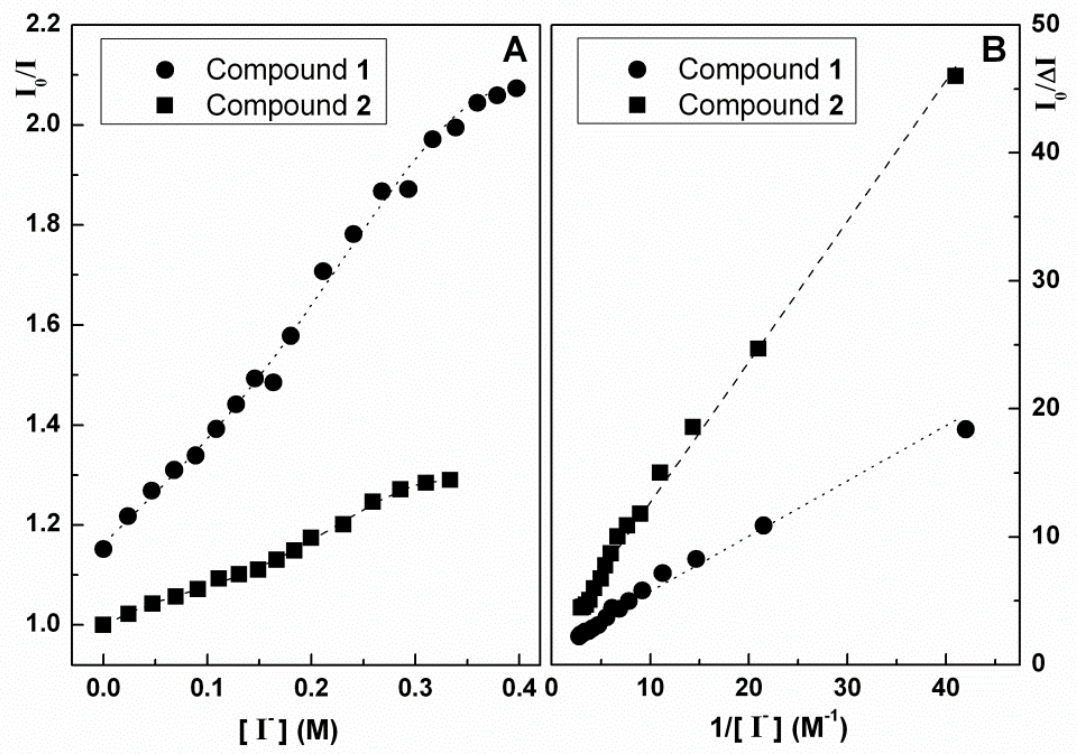

Figure 10. A: Stern-Volmer plots for quenching with iodide ion ( $\left.\mathrm{I}^{-}\right)$for compounds $\mathbf{1}$ and $\mathbf{2}$ with salmon sperm DNA at total binding, $[\mathrm{DNA}] /[$ compound] $=100$. B: Corresponding modified SternVolmer plots.

The fraction of intercalated molecules into salmon sperm DNA and heteropolynucleotides is higher for the benzothienoquinoline 1 ( $46 \%$ to $49 \%$ ). On the contrary, compound 2 presents a very small fraction of intercalated molecules $(8 \%)$ in poly $(\mathrm{dG}-\mathrm{dC}) .(\mathrm{dG}-\mathrm{dC})$, while in poly $(\mathrm{dA}-$ dT).(dA-dT) the percentage is similar to the observed in natural DNA (around 40\%). As both quinolines $\mathbf{1}$ and $\mathbf{2}$ are neutral molecules, the relatively high values for $f_{\mathrm{a}}$ indicate that groove binding is an important type of interaction of these quinoline derivatives to DNA [24,31] (electrostatic interaction is not expected), being compound $\mathbf{1}$ the more intercalative one.

In order to further characterize the interaction of benzothienoquinolines $\mathbf{1}$ and $\mathbf{2}$ with DNA, docking studies using autodock [36] were performed, for a crystallographic dodecamer $B$-DNA (1HQ7: GCAAACGTTTGC sequence [37]) and a structure with nine base pairs intercalated with benzo[a]pyrene diol epoxide (BaP) (1DXA: GGTC[BaP]ACGAG sequence [37]) from which the intercalator was removed (1DXA*). The setup of the autodock calculation (10 runs, 270000 maximum number of generations, 2500000 maximum number of energy evaluations, $112 \times 74 \times 62$ grid points for $1 \mathrm{HQ} 7$ and $76 \times 72 \times 62$ for $1 \mathrm{DXA} *$ with $0.375 \AA$ spacing) and visualization of the results were made with the help of the autodocktools software suite (ADT) [38]. Figure 11 shows the results of the most stable docked structures for the studied compounds and for the highly efficient $\mathrm{B} a \mathrm{P}$ intercalator. The values of the binding energies obtained are reported in Table 5. 


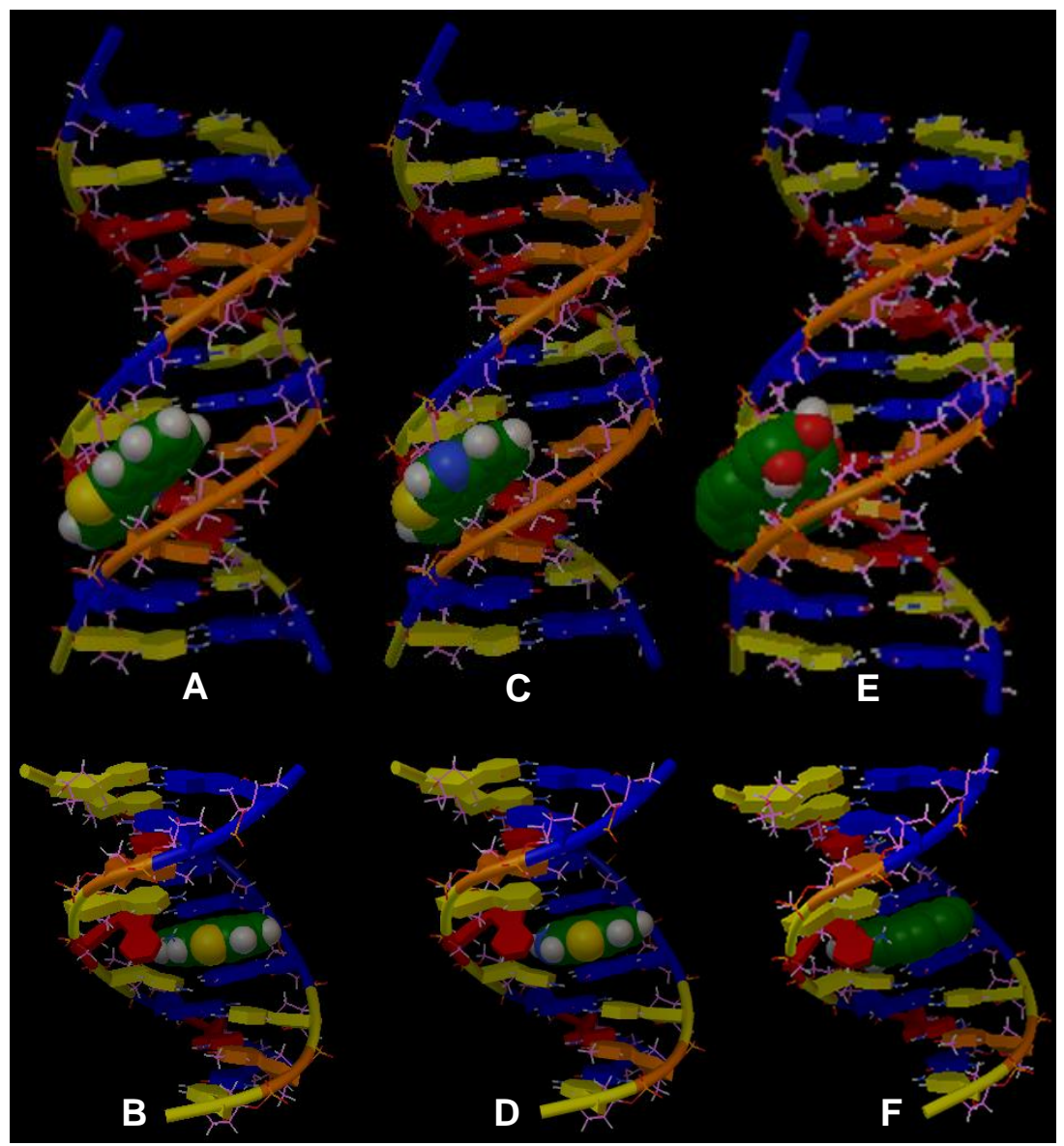

Figure 11. Compound 1 - A: Docking in 1HQ7; B: Docking in 1DXA*. Compound 2 - C: Docking in 1HQ7; D: Docking in 1DXA*. Benzo[a]pyrene diol epoxide - E: Docking in 1HQ7; F: Docking in 1DXA*.

Two types of docking in polynucleotides are usually considered: direct (self) docking and cross dockings [39]. Only docking F (Table 5 and Figure 11) is a direct one, as it corresponds to the rebinding of a molecule that was removed from the polynucleotide structure where it was originally included. For the purpose of this work, it serves as a control for the effectiveness of the docking procedure and as a reference for evaluation of the other docking results. As expected, intercalation does not occur in 1HQ7, even for a very efficient intercalator such as $\mathrm{B} a \mathrm{P}$, because the polynucleotide structure, which is rigid during the docking procedure, does not include an appropriate intercalating gap. From Table 5, it is possible to conclude that the interaction of compound $\mathbf{1}$ with DNA is always stronger than that for compound $\mathbf{2}$, with the less favorable situation occurring for the intercalation of compound 2 in 1DXA*. For $\mathrm{B} a \mathrm{P}$, intercalation in 1DXA* and minor groove binding in $1 \mathrm{HQ} 7$ are equally favorable. As $\mathrm{B} a \mathrm{P}$ is known to interact with DNA by intercalation, it seems that, for a sufficiently high release of free energy as the polynucleotide structure has to accommodate the guest molecule, 
intercalation is the preferred mode of binding. Thus, noting that intercalation of compound $\mathbf{2}$ is the less favorable interaction with $1 \mathrm{DXA} *\left(-7 \mathrm{kcal} \mathrm{mol}^{-1}\right)$, and taking also into account both the different spectral behavior of the compounds upon DNA interaction and the higher accessibility of iodide ion to compound 2 binding sites, the docking results support a higher fraction of intercalation for compound $\mathbf{1}$ than for compound $\mathbf{2}$. The binding free energy of compound $\mathbf{1}$ to 1DXA* by intercalation is significant, as the intercalation gap corresponds to $\mathrm{B} a \mathrm{P}$ (crossdocking). In a reported docking study [39], cross-docking of elliptine (a typical intercalating agent) with a polynucleotide in which an intercalation gap was constructed (adapted for elliptine) gave a binding free energy of $-8.1 \mathrm{kcal} \mathrm{mol}^{-1}$, while the corresponding self-docking showed a value of $-8.7 \mathrm{kcal} \mathrm{mol}^{-1}[39]$.

Table 5. Docking results for the interaction of the studied compounds and benzo[ $a]$ pyrene diol epoxide with model nucleic acid sequences using autodock software. ${ }^{\mathrm{a}}$

\begin{tabular}{|c|c|c|c|c|c|c|}
\hline & Docking & Nucleic acid & Type of binding & $\mathrm{N}_{\mathrm{b}}(\%)$ & $\begin{array}{c}\text { Lower } \Delta \mathrm{G}_{\mathrm{i}} \\
(\mathrm{kcal} / \mathrm{mol})\end{array}$ & $\begin{array}{c}\text { Average } \Delta \mathrm{G}_{\mathrm{i}} \\
(\mathrm{kcal} / \mathrm{mol})\end{array}$ \\
\hline \multirow{4}{*}{ Compound 1} & \multirow{2}{*}{ A } & \multirow{2}{*}{ 1HQ7 } & minor groove & $\begin{array}{l}80 \\
20\end{array}$ & $\begin{array}{l}-10.33 \\
-9.74\end{array}$ & $\begin{array}{l}-10.31 \\
-9.74\end{array}$ \\
\hline & & & intercalation & & --- & \\
\hline & \multirow{2}{*}{ B } & \multirow{2}{*}{ 1DXA* } & minor groove & & --- & \\
\hline & & & intercalation & 100 & -8.24 & -8.23 \\
\hline \multirow{5}{*}{ Compound 2} & \multirow{3}{*}{$\mathrm{C}$} & \multirow{3}{*}{ 1HQ7 } & \multirow{2}{*}{ minor groove } & 90 & -7.97 & -7.95 \\
\hline & & & & 10 & -7.32 & -7.32 \\
\hline & & & intercalation & & --- & \\
\hline & \multirow{2}{*}{$\mathrm{D}$} & \multirow{2}{*}{ 1DXA* } & minor groove & & --- & \\
\hline & & & intercalation & 100 & -7.05 & -7.01 \\
\hline \multirow{8}{*}{$\begin{array}{c}\text { Benzo }[a] \text { pyren } \\
\text { e } \\
\text { diol epoxide }\end{array}$} & \multirow{5}{*}{$\mathrm{E}$} & \multirow{5}{*}{ 1HQ7 } & \multirow{4}{*}{ minor groove } & 40 & -9.74 & -9.43 \\
\hline & & & & 10 & -9.53 & -9.53 \\
\hline & & & & 40 & -9.40 & -9.03 \\
\hline & & & & 10 & -8.95 & -8.95 \\
\hline & & & intercalation & & --- & \\
\hline & \multirow{3}{*}{$\mathrm{F}$} & \multirow{3}{*}{ 1DXA* } & minor groove & 10 & -8.16 & -8.16 \\
\hline & & & \multirow{2}{*}{ intercalation } & 60 & -9.84 & -9.75 \\
\hline & & & & 30 & -8.62 & -8.59 \\
\hline
\end{tabular}

${ }^{\mathrm{a}} \mathrm{N}_{\mathrm{b}}$ : percentage of runs in minor groove or intercalation binding mode; $\Delta \mathrm{G}_{\mathrm{i}}$ : binding free energy.

From the docked structures shown in Figure 11, it is also possible to observe that the nitrogen atom of compound $\mathbf{2}$ is more exposed to the medium surrounding DNA than that of compound 1. This, along with the distinct binding modes, could be the reason for a decrease of fluorescence intensity upon DNA binding, instead of the observed increase in the case of compound 1. 


\section{CONCLUSIONS}

A new one pot method was achieved for the synthesis of benzothieno[3,2-b]quinoline 1 and benzothieno[2,3-c] quinoline $\mathbf{2}$ by the reaction of the commercial available 3bromobenzo $[b]$ thiophene-2-carbaldehyde with 2-aminophenylpinacolborane under Suzuki coupling conditions using a stereochemically hindered ligand, 2(cyclohexylphosphane)biphenyl and $\mathrm{Ba}(\mathrm{OH})_{2} .8 \mathrm{H}_{2} \mathrm{O}$ as the base. Although the compounds have already been synthesized earlier by other authors using several steps, our methodology is advantageous saving reagents and time. Both compounds are fluorescent and present a solvent sensitive emission, despite the low fluorescence quantum yields (below 10\%).

The benzothieno[3,2-b]quinoline $\mathbf{1}$ is the most intercalative compound in DNA and synthetic heteropolynucleotides. Both compounds exhibit a stronger interaction with A-T than with G-C base pairs, exhibiting higher binding constants and smaller binding site sizes. Fluorescence quenching measurements allowed concluding that the interaction with DNA of these quinoline derivatives is both intercalation and binding in the grooves.

Docking studies indicate that compound 1 interacts more strongly with DNA than compound 2, with a significant value of binding free energy in the case of intercalation. Minor groove binding is also very favorable and, probably, both mechanisms occur with a preponderance of intercalation in the case of compound 1. The docked structures showed that in compound 2 the nitrogen atom is exposed to the medium surrounding DNA. This should also contribute to the different spectral behavior of both compounds upon DNA interaction reported in this study.

\section{ACKNOWLEDGEMENTS}

Foundation for the Science and Technology (FCT, Portugal), for financial support to the Portuguese NMR network (PTNMR) and also to FEDER and QREN for financial support to the Research Centres, CFUM [Strategic Project PEst-C/FIS/UI0607/2013 (FCOMP-01-0124FEDER-037291)] and CQ/UM [Strategic Project PEst-C/QUI/UI0686/2013 (FCOMP-01-0124FEDER-037302)], and to the research project PTDC/QUI-QUI/111060/2009 (F-COMP-010124-FEDER-015603) also financed by COMPETE/QREN/EU. FCT, POPH-QREN and FSE are acknowledged for the PhD grants of A.R.O.R. (SFRH/BD/90949/2012) and M.S.D.C. (SFRH/BD/47052/2008), for the Post-Doc. Grant of R.C.C. (SFRH/BPD/68344/2010) and for support to MAP-Fis Doctoral Program. 


\section{REFERENCES}

[1] X.L. Yang, A.H.J. Wang, Structural studies of atom-specific anticancer drugs acting on DNA, Pharmacol. Ther. 83 (1999) 181-215.

[2] L.B. McGown, M.J. Joseph, J. B. Pitner, G.P. Vonk, C.P. Linn, The nucleic-acid ligand - A new tool for molecular recognition, Anal. Chem. 67 (1995) 663A-668A.

[3] P.D. Lyne, Structure-based virtual screening: an overview, Drug Disc. Today 7 (2002) 1047-1055.

[4] S. Mahadevan, M. Palaniandavar, Spectroscopic and voltammetric studies of copper(II) complexes of bis(pyrid-2-yl)-di/trithia ligands bound to calf thymus DNA, Inorg. Chim. Acta 254 (1997) 291-302.

[5] X.Y. Zhu, L.G. Mardenborough, S.M. Li, A. Khan, W. Zhang, P.C. Fan, M. Jacob, S. Khan, L. Walker, S.Y. Ablordeppey, Synthesis and evaluation of isosters of $N$ methylindole[3,2- $b$ ]quinoline (cryptolepine) as new anti-infective, Bioorg. Med. Chem. 15 (2007) 686-695.

[6] a) J.D. McKenney Jr, R.N. Castle, The synthesis of [1]benzothieno[2,3-c]quinolines, [1]benzothieno[2,3-c][1,2,4]triazolo[4,3-a]quinoline and [1]benzothieno[2,3c]tetrazolo[1,5-a]quinolone, J. Heterocycl. Chem. 24 (1987) 1525-1529. b) A.Z. Zektzer, M.J. Quast, G.S. Linz, G.E. Martin, J.D. McKenney, M.D. Johnston Jr, R.N. Castle, New pulse sequence for long-range two-dimensional heteronuclear NMR chemical shift correlation, Magn. Reson. Chem. 24 (1986) 1083-1088.

[7] G. Dougherty, J.R. Pilbrow, Physicochemical probes of intercalation, Int. J. Biochem. 16 (1984) 1179-1192.

[8] H. Fritzsche, A. Akhebat, E. Taillandier, K. Rippe, T.M. Jovin, Structure and druginteractions of parallel-stranded DNA studied by infrared-spectroscopy and fluorescence, Nucleic Acid Res. 21 (1993) 5085-5091.

[9] D. Pang, H.D. Abruna, Micromethod for the investigation of the interactions between DNA and redox active molecules, Anal. Chem. 70 (1998) 3162-3169.

[10] P.J. Gane, P.M. Dean, Recent advances in structure-based rational drug design, Curr. Opin. Struct. Biol. 10 (2000) 401-404. 
[11] D.E. Graves, L.M. Velea, Intercalative binding of small molecules to nucleic acids, Curr. Org. Chem. 4 (2000) 915-929.

[12] E. Renault, M.P. Fontaine-Aupart, F. Tfibel, M. Gardes-Albert, E. Bisagni, Spectroscopic study of the interaction of pazelliptine with nucleic acids, J. Photochem. Photobiol. B: Biol. 40 (1997) 218-227.

[13] M.-J.R.P. Queiroz, E.M.S. Castanheira, M.S.D. Carvalho, A.S. Abreu, P.M.T. Ferreira, H. Karadeniz, E. Arzum, New tetracyclic heteroaromatic compounds based on dehydroamino acids: photophysical and electrochemical studies of interaction with DNA, Tetrahedron 64 (2008) 382-391.

[14] C.V. Kumar, E.H. Asuncion, DNA-binding studies and site-selective fluorescence sensitization of an anthryl probe, J. Am. Chem. Soc. 115 (1993) 8547-8553.

[15] C.V. Kumar, E.H.A. Punzalan, W.B. Tan, Adenine-Thymine base pair recognition by an anthryl probe from the DNA minor groove, Tetrahedron 56 (2000) 7027-7040.

[16] J.N. Demas, G.A. Crosby, Measurement of photoluminescence quantum yields - Review, J. Phys. Chem. 75 (1971) 991-1024.

[17] S. Fery-Forgues, D.J. Lavabre, Are fluorescence quantum yields so tricky to measure? A demonstration using familiar stationery products, J. Chem. Educ. 76 (1999) 1260-1264.

[18] J.V. Morris, M.A. Mahaney, J.R. Huber, Fluorescence quantum yield determinations 9,10-diphenylanthracene as a reference-standard in different solvents, J. Phys. Chem. 80 (1976) 969-974.

[19] Y. Cao, X.-w. He, Studies of interaction between Safranine T and double helix DNA by spectral methods, Spectrochim. Acta Part A 54 (1998) 883-892.

[20] J.D. McGhee, P.H. von Hippel, Theoretical aspects of DNA-protein interactions Cooperative and non-cooperative binding of large ligands to a one-dimensional homogeneous lattice, J. Mol. Biol. 86 (1984) 469-489.

[21] W.J. Thompson, J.H. Jones, P.A. Lyle, J.E. Thies, An efficient synthesis of arylpyrazines and bipyridines, J. Org. Chem. 53 (1988) 2052-2055.

[22] M.-J.R.P. Queiroz, S. Dias, D. Peixoto, A.R.O. Rodrigues, A.D.S. Oliveira, P.J.G. Coutinho, A. Vale-Silva, E. Pinto, E.M.S. Castanheira, New potential antitumoral di(hetero)arylether derivatives in the thieno[3,2-b]pyridine series: Synthesis and 
fluorescence studies in solution and in nanoliposomes, J. Photochem. Photobiol. A: Chem. 238 (2012) 71-80.

[23] M.-J.R.P. Queiroz, D. Peixoto, A.R.O. Rodrigues, P.M.F. Mendes, C.N.C. Costa, P.J.G. Coutinho, E.M.S. Castanheira, New 1,3-diarylureas linked by C-C Suzuki coupling to the methyl 3-aminothieno[3,2-b]pyridine-2-carboxylate moiety: synthesis and fluorescence studies in solution and in lipid membranes, J. Photochem. Photobiol. A: Chem. 255 (2013) 27-35.

[24] E.M.S. Castanheira, M.S.D. Carvalho, A.R.O. Rodrigues, R.C. Calhelha, M.-J.R.P. Queiroz, New potential antitumoral fluorescent tetracyclic thieno[3,2- $b$ ]pyridine derivatives: Interaction with DNA and nanosized liposomes, Nanoscale Res. Lett. 6 (2011) article 379.

[25] K.C. James, P.R. Noyce, Hydrogen bonding between testosterone propionate and solvent in chloroform-cyclohexane solutions, Spectrochim. Acta A, 27 (1971) 691-696.

[26] G.R. Wiley, S.I. Miller, Thermodynamic parameters for hydrogen-bonding of chloroform with Lewis bases in cyclohexane - Proton magnetic-resonance study, J. Am. Chem. Soc. 94 (1972) 3287-3293.

[27] Gaussian 09, Revision A.02, M.J. Frisch, G.W. Trucks, H.B. Schlegel, G.E. Scuseria, M.A. Robb, J.R. Cheeseman, G. Scalmani, V. Barone, B. Mennucci, G.A. Petersson, H. Nakatsuji, M. Caricato, X. Li, H.P. Hratchian, A.F. Izmaylov, J. Bloino, G. Zheng, J.L. Sonnenberg, M. Hada, M. Ehara, K. Toyota, R. Fukuda, J. Hasegawa, M. Ishida, T. Nakajima, Y. Honda, O. Kitao, H. Nakai, T. Vreven, J.A. Montgomery Jr., J.E. Peralta, F. Ogliaro, M. Bearpark, J.J. Heyd, E. Brothers, K.N. Kudin, V.N. Staroverov, R. Kobayashi, J. Normand, K. Raghavachari, A. Rendell, J.C. Burant, S.S. Iyengar, J. Tomasi, M. Cossi, N. Rega, J.M. Millam, M. Klene, J.E. Knox, J.B. Cross, V. Bakken, C. Adamo, J. Jaramillo, R. Gomperts, R.E. Stratmann, O. Yazyev, A.J. Austin, R. Cammi, C. Pomelli, J.W. Ochterski, R.L. Martin, K. Morokuma, V.G. Zakrzewski, G.A. Voth, P. Salvador, J.J. Dannenberg, S. Dapprich, A.D. Daniels, Ö. Farkas, J.B. Foresman, J.V. Ortiz, J. Cioslowski, D.J. Fox, Gaussian, Inc., Wallingford CT, 2009.

[28] F. Jensen, Introduction to Computational Chemistry, John Wiley \& Sons, West Sussex, 1999.

[29] T. Le Bahers, C. Adamo, I. Ciofini, A Qualitative Index of Spatial Extent in ChargeTransfer Excitations, J. Chem. Theory Comput. 7 (2011) 2498-2506. 
[30] L. Tian, C. Feiwu, Multiwfn: A Multifunctional Wavefunction Analyzer, J. Comput. Chem. 33 (2012) 580-592.

[31] M.-J.R.P. Queiroz, E.M.S. Castanheira, T.C.T. Lopes, Y.K. Cruz, G. Kirsch, Synthesis of fluorescent tetracyclic lactams by a "one pot" three steps palladium-catalyzed borylation, Suzuki coupling (BSC) and lactamization. DNA and polynucleotides binding studies. J. Photochem. Photobiol. A: Chem. 190 (2007) 45-52.

[32] V.Y. Shafirovich, P.P. Levin, V.A. Kuzmin, T.E. Thorgeirsson, S.D. Kliger, N.E. Geacintov, Photoinduced electron transfer and enhanced triplet yields in benzo[ $a]$ pyrene derivative-nucleic acid complexes and covalent adducts, J. Am. Chem. Soc. 116 (1994) 63-72.

[33] M.E.C.D.R. Oliveira, A.L.F. Baptista, P.J.G. Coutinho, E.M.S. Castanheira, G. Hungerford, Fluorescence studies of the interaction of pyrenylmethyl tributylphosphonium bromide with double-strand polynucleotides, Photochem. Photobiol. Sci. 3 (2004) 217-225.

[34] B. Valeur, Molecular Fluorescence - Principles and Applications, Wiley-VCH, Weinheim, 2002.

[35] S.S. Lehrer, Solute perturbation of protein fluorescence. Quenching of tryptophyl fluorescence of model compounds and of lysozyme by iodide ion, Biochemistry 10 (1971) 3254-3263.

[36] G.M. Morris, D.S. Goodsell, R.S. Halliday, R. Huey, W.E. Hart, R.K. Belew, A.J. Olson, Automated docking using Lamarckian Genetic Algorithm and an empirical binding free energy function, J. Comput. Chem. 19 (1998) 1639-1662.

[37] http://www.rcsb.org/pdb/home/home.do; accessed on march 23, 2014.

[38] M.F. Sanner, Python: a programming language for software integration and development, J. Mol. Graph Model. 17 (1999) 57-61.

[39] C.G. Ricci, P.A. Netz, Docking Studies on DNA-Ligand Interactions: Building and Application of a Protocol to Identify the Binding Mode, J. Chem. Inf. Model. 49 (2009) 1925-1935. 